BUSINESS

\section{Fears rise over leaks of clinical trial results}

$\square_{a}^{h}$ hysicians in the United States are facing a fresh conflict-of-interest scandal over allegations that many of them accept cash for briefing financial analysts about the progress of clinical trials.

Thousands of doctors are paid to participate in teleconferences with stock-market analysts. And although most doctors say they are careful not to divulge confidential data, critics of such briefings say they wouldn't happen unless investors gleaned inside knowledge from them.

Senator Chuck Grassley (Republican, Iowa), chairman of the senate finance committee, last month demanded that both the Department of Justice and the Securities and Exchange Commission look into the practice, after a Seattle Times investigation cited 26 alleged examples of confidential leaks from ongoing drug trials.

Any investigation is likely to focus on hedge funds - loosely regulated financial instruments that allow investors to gamble on sharp movements of particular stocks.

Critics contend that physicians' responses to seemingly innocuous questions about drug performance serve as useful data for stock analysts. Professional bodies such as the Association of Clinical Research Professionals say they are watching the issue closely but have no authority to address it - although this might change if ethical standards are revised. PhRMA, the drug-industry organization, said in a statement: ${ }^{\circ}$ Our laws are meant to protect patients, future research and the public. Breaking these laws is a reprehensible breach of trust and we condemn it."

Defenders of the briefings argue that talking to doctors directly is the best way for people issuing advice on drug-development investments to stay informed. In recent years, 'matchmaker' companies have been created to facilitate such conversations. The Gerson Lehrman Group (GLG) based in New York is the largest matchmaker with some 60,000 physician dients.

Hourly fees that run from $\$ 200$ up to $\$ 1,000$ signal the importance placed on this information. Because pharmaceutical industries do not publish data from their own failed trials and independent researchers are often constrained by non-disclosure agreements, every bit of information provides a competitive edge for investors, says Charles Firneno, industry analyst with Life Science Insights, a marketresearch company based in Framingham,

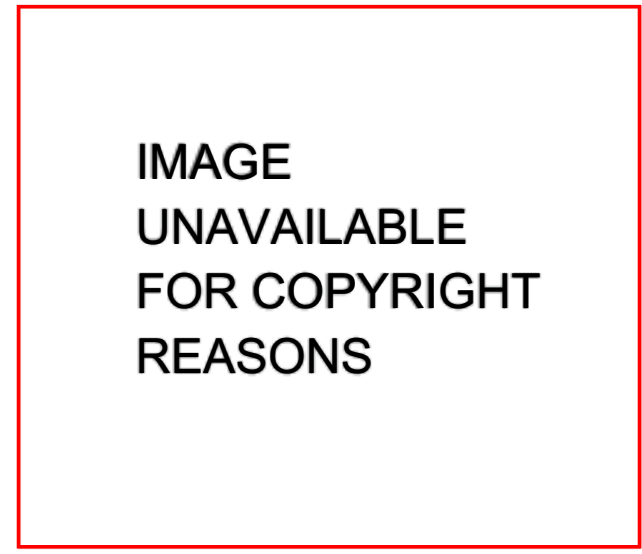

Eric Topol (right) is opposed to the briefing of financial analysts by doctors involved indrug trials.

Massachusetts. Just one statement made by a physician can influence share price, he adds: "That situation is a clear conflict."

Investors can also use the information to sell stocks short, where trials indicate problems with a drug. Eric Topol, a cardiologist at the Cleveland Clinic in Ohio and former paid consultant, has publidydescribed investor practices used to obtain critical drug-trial information (E. J. Topol and D. Blumenthal J. Am. Med. Assoc. 293, 2654-2657; 2005). The paper was published after Topol had been accused by Forbes magazine of providing insider information to a hedge fund which sold Merck stock short before problems with its painkiller Vioxx became publiclast October. "Managing the potential conflict is virtually impossible," says Topol.

The appearance of impropriety is enough for some to decline such consulting offers. Brian Druker, a Howard Hughes Medical Investigator at Oregon Health \& Sciences University in Portland, left GLG two years ago on ethical grounds. It wasn't possible to be sure that he could always remember what was public, and what was confidential, he says.

"At its most egregious, this is a deliberate effort to unblind dinical trials for short-term profits," says Stanley Crooke, chief executive of Isis Pharmaceuticals, a company based in Carlsbad, $\mathrm{Cal}$ ifornia, whose stock dropped $20 \%$ in late 2002 after an industry report leaked problems with Isis leukaemia drug Affinitak. At the very least, it undermines the public's confidence in the drug approval process, Crooke says.

Virginia Gewin

\section{IN BRIEF}

NOVARTIS GRABS CHIRON

Swiss-based drugmaker Novartis has offered to buy out California vaccine manufacturer Chiron for US\$4.5billion.

The bid was made as the US Food and Drug Administration said it thought Chironwas making "significant progress" in addressing problems at its production plant in Liverpool, UK. Chironstock has been depressed since UK regulators ordereditto cease production in Liverpool of its fluvaccine, Fluvirin, last October.

Analysts say that Novartis is moving to procure Chironat a bargain price at a time when concerns about a global flu epidemic could boost the vaccine company's prospects.

Novartis already owns $42 \%$ of Chiron; it will buy the rest if its offer is accepted by most other shareholders.

\section{CLOUD OVER SATELLITES Even}

as hurricane Katrina devastated the southern United States, industry officials admitted that a major weather satellite programme is running two years late and billions of dollars over budget.

Officials at Northrop Grumman in Los Angeles, the defence contractor that is building the satellites for the Department of Defense, told a conference in California that delays were due to problems with integrating many different types of sensor into the satellites.

The programme is now expected to be functional in $\mathbf{2 0 1 0}$ at the earliest and to cost much more than the originalestimate of $\$ 4.5$ billion.

NANOTECHIN MEDICINE Sales of medicalproducts and equipment that use nanotechnology will grow strongly, a marketresearch firm says - but perhaps not by enough to support the flood of activity in the sector.

Frost \& Sullivan predicts that the world nanobiotechnology mar ket - basically the use of nanoscale materials and devices for drug delivery, tissue reconstruction and other medical ap plications - will grow from US\$750 million last year to about $\$ 2$ billion by 2011.

But the company warns that too many players are joining the field and that regulatory obstacles could make it hard for nanotech-based products to compete. 